Revista Transgressões: ciências criminais em debate, v. 4, n.2, Novembro 2016, Natal/RN

\title{
Ponto e nó de linha rota
}

\author{
Isadora Dourado Rocha
}

Graduanda em Direito pela Universidade de Brasília.

E-mail: isadoradouradorocha@gmail.com

Vovó sempre se sentava nas cadeiras de fio frente a casa quando o sol se baixava. Das histórias que ali ela ouvia, dos vizinhos e passantes, sempre dizia que "quem conta um conto, aumenta um ponto". E dos pontos que ela me ensinou, como bordadeira que é, o que interessa é o avesso: é nele que reside a qualidade dum bom trabalho. $\mathrm{O}$ que não se vê à primeira vista, que se esconde, o forro, a anágua, o segredo da receita: era isso o que aguçava o paladar, ela dizia. Só vendo o avesso pra saber se o bordado estava mesmo bem entremeado.

De tempos em tempos, ela não sabia precisar quando com seus já cabelos brancos pintados de vermelho, passava um homem de jaleco, dum instituto do governo, querendo contar as pessoas. Depois anunciava o prefeito que, na contagem, deram duas mil cento e trinta e uma pessoas. Nenhuma era médica. Nenhuma era delegada. Nenhuma juíza e nenhuma promotora. Cinco polícias, mas uma nem morava ali, só vinha trabalhar no quartel. Nenhuma era dona de rádio, jornal ou tevê local. O homem de jaleco, vovó disse que ele a contou, deixou de passar na casa dum ladrão de galinha, tinha certa desavença com o ladrão de varal - deixando também a casa deste -, e achou que não valia a pena passar na casa do doidinho que joga pedra em quem o chama.

Convencionaram, pessoas do exterior, chamar ali de interior. São duas ruas - avenidas - principais que se cruzam duas quadras acima da praça central, onde fica a igreja e, atrás desta, o postinho de saúde. A rodoviária ficava logo abaixo e, de movimento, apenas um ônibus que vinha da cidade 
vizinha uma vez por dia, cheio de gatos pingados. A casa do prefeito ficava ali nos arredores, bem perto do quartel, e era a única que tinha dois andares: vovó dizia que de lá de cima se via até depois da rodovia.

A dinda sempre se gabava pras primas do exterior de como era bom morar ali - tão seguro! Nunca acontece nada. Quer dizer, não posso deixar os meninos irem na praça à noite nem tomar um lanche, acredita que aqui já tem maconheiro? Mas o carro do quartel agora fica lá rondando e leva eles pro Conselho Tutelar. Melhorou muito, mas esse tal de Conselho, agora nem pode mais levantar a mão, não.

Vovó inda completava: nem trânsito tem, olha que beleza. Colocaram um redutor de velocidade e um pardal antes da rodovia, mas nem dois dias, já era, quebrou! A gente faz tudo andando, deixa tudo aberto, não é ótimo? Nunca acontece nada. Quando acontece é uma briguinha e aí é só a gente esperar acalmar, né, e no outro dia a gente vê se tá tudo bem.

E eu, saindo do segundo período de faculdade no exterior toda sexta, indo passar o fim de semana enrolando roscas com vovó, cada dia mais perplexa. Eu lia e relia - a semana toda - que o controle social a que o Estado se atribui - ainda que nem sempre explicitamente - vai até o mais simples ato individual. Que o controle penal, faceta mais poderosa desse controle, seleciona os socialmente indesejáveis através da polícia, do sistema judiciário, da imposição de pena. E junto disso eu lia todos os compêndios ensinando como é a lei, como ela é interpretada e aplicada. Pareciam dois mundos de conversadores e eu não os via... conversando.

E ali, no meu tempo livre, naquele interior de duas avenidas e uma praça e a casa de vovó de roscas húngaras cheirosas, ali eu não via nada daquilo. Não havia delegacia, fórum, promotoria, departamento de trânsito, hospital, rede de televisão nem de rádio. A calmaria parecia sempre reinar, parecia um mundo náo estudado - eu já me acostumava a por o óculos e objetificar. Onde estavam os sistemas de controle? Eu não os via e tudo parecia tão ao gosto da ordem. Parecia um contrassenso.

Em um dos fins de semana lá, um sábado de festa da padroeira da cidade, eu acordei com gritos. Até entender que eram gritos duma briga na casa vizinha - onde morava um pastor e sua família - e que a voz de quem gritava era bem parecida com a minha, e tentar fazer algo, já tinha se passado tempo demais e vovô acendeu a lâmpada da sala me dizendo que eu não deveria sair: não era assunto meu.

Outra vez, meu primo veio me contar, todo faceiro, que foi mandado ao Conselho Tutelar por ter quebrado um banco na praça com uns amigos. No Conselho, ele viu uma pessoa gritando com um menino - "baixinho, 
sempre fica descalço pedindo o lanche na praça” meu primo o descreveu - e essa pessoa gritando muito alto que já era a quinta vez que pegavam o menino fumando maconha, que assim não dava, que não era possível que ele ainda não tivesse levado um corretivo, que era uma pena não ter mais Febem lá perto.

Inda outro dia, vovó disse que tinha levado um susto durante a semana. Um moleque roubando duas de suas galinhas carijó, imagine. Ainda bem que o carro da polícia do quartel passava em ronda toda noite e escutou os gritos, mesmo sendo tarde da noite. Eles entraram antes que vovô, com seu revólver de cabo de madrepérola de segundo-tenente aposentado, atirasse. E levaram o ladrãozinho de galinha para passar uma noite no quartel. Era até o mesmo que o contador de pessoas não contou, já conhecido ali, vovó disse.

E eu ainda achava que não havia controle algum. Terra sem lei onde sequer ela era necessária. Achava que não havia então os males da seleção, do etiquetamento, todos tratados iguais, a utopia liberal se realizando. Estava quase me sentindo observando um novo paradigma digno de minha monografia - eu me elevava alto com meus óculos.

Até que me lembrei que ponto bem dado se vê pela qualidade do avesso. E o avesso, mesmo que a linha esteja desde sempre podre, esse fica sempre escondido. Não se sai dessa trama. Não interessa que o bordado esteja bem bordado, ele ainda contém, ainda mantém a figura. É um retângulo verde que acolhe um losango amarelo e um círculo azul: só parece reinar a calmaria. 